\title{
Determination of the Compressive Strength of Concrete from Binary Cement and Ternary Aggregates
}

\author{
Oluwatosin Babatola, Chinwuba Arum \\ Department of Civil Engineering, Federal University of Technology, Akure, Nigeria \\ Email: tosinbabatola1991@gmail.com,carum@futa.edu.ng
}

How to cite this paper: Babatola, O. and Arum, C. (2020) Determination of the Compressive Strength of Concrete from Binary Cement and Ternary Aggregates. Open Journal of Civil Engineering, 10, 385-402.

https://doi.org/10.4236/ojce.2020.104029

Received: November 5, 2020

Accepted: December 19, 2020

Published: December 22, 2020

Copyright $\odot 2020$ by author(s) and Scientific Research Publishing Inc. This work is licensed under the Creative Commons Attribution International License (CC BY 4.0).

http://creativecommons.org/licenses/by/4.0/

\begin{abstract}
One of the most active fields of research embraced by many disciplines, including civil engineering, is material reuse. It is known that ceramics wastes from various construction and demolition sites and manufacturing processes are dumped away into the environment, resulting in the pollution that threatens both agriculture and public health. Therefore, the utilization of ceramic waste in construction industries would help to protect the environment from such pollutions. This paper presents the results of an experimental analysis of the effects of partial replacement of coarse aggregates, fine aggregates, and ordinary Portland cement with the ceramic waste, at percentage levels of $0 \%, 5 \%, 10 \%$, and $20 \%$; and the assessment of the strength property of the concrete produced with optimum combination of the constituents. Compressive strengths of this concrete were determined at 7, 28, and 56 days of curing using $150 \times 150 \times 150 \mathrm{~mm}$ cube specimens. Test results showed that the compressive strength of the concrete decreased as the content of ceramic waste present in the concrete increased. Thus, concrete produced from the partial replacement of ordinary Portland cement with ground ceramics gave compressive strengths of $16.6 \mathrm{~N} / \mathrm{mm}^{2}$ and $13.4 \mathrm{~N} / \mathrm{mm}^{2}$ at $5 \%$ and $20 \%$ replacement levels respectively. Similarly, the compressive strengths of concrete from the partial replacement of sand with fine ceramics were $13.8 \mathrm{~N} / \mathrm{mm}^{2}$ and $10.9 \mathrm{~N} / \mathrm{mm}^{2}$ for $5 \%$ and $20 \%$ replacements respectively. For $5 \%$ and $20 \%$ replacement levels of granite with crushed ceramics in concrete gave a compressive strength of $11.6 \mathrm{~N} / \mathrm{mm}^{2}$ and $9.7 \mathrm{~N} / \mathrm{mm}^{2}$, respectively. For concrete derived from the partial replacement of stone dust with fine ceramics, the compressive strengths were $19.6 \mathrm{~N} / \mathrm{mm}^{2}$ and $18.10 \mathrm{~N} / \mathrm{mm}^{2}$ respectively for $5 \%$ and $20 \%$. For concrete produced from the partial replacement of bush gravel with crushed ceramics, the compressive strengths obtained were 10.9 $\mathrm{N} / \mathrm{mm}^{2}$ and $8.98 \mathrm{~N} / \mathrm{mm}^{2}$ respectively for $5 \%$ and $20 \%$ replacements. Finally,
\end{abstract}


the concrete derived from the optimal combination of binary cement, ternary fine, and coarse aggregate had a compressive strength of $22.20 \mathrm{~N} / \mathrm{mm}^{2}$ which is higher than the compressive strength of the control mixture at 18.10 $\mathrm{N} / \mathrm{mm}^{2}$. The result of the ANOVA carried out showed that the compressive strength obtained for each partial replacement of different components is statistically significant at $5 \%$, i.e. the change in the compressive strength of the concrete produced is due to the presence of ceramic waste.

\section{Keywords}

Ceramic Waste, Aggregate, Compressive Strength, Setting Time, Ordinary Portland Cement

\section{Introduction}

Concrete is among the most important building materials in civil engineering [1]. While concrete in construction contributes to socio-economic growth in both developed and developing countries, it is clear that some of its operations produce several negative changes to the natural environment. The high cost of cement in Nigeria, the negative environmental effects of its production, the high energy demand, the rapid depletion of natural raw materials for the production of Portland cement, all lead to reducing the attractiveness of Portland cement [2]. The high use of natural materials for concrete production lowers the stock of natural materials in the world. If this trend of usage persists, there will be fewer natural resources available in the future, and there is no question that the energy required to extract the declining supplies and the distance of transport will increase [3]. Cement, which is also one of the most important components of concrete, is energy-intensive in its production [4]. Due to the de-carbonation of the raw materials $\left(\mathrm{CO}_{2}-\mathrm{D}\right)$ and those produced from the kiln $\left(\mathrm{CO}_{2}-\mathrm{K}\right)$, cement plants have made attempts to minimize the release of both $\mathrm{CO}_{2}\left(\mathrm{CO}_{2}-\mathrm{D}\right.$ and $\left.\mathrm{CO}_{2}-\mathrm{K}\right)$. When part of the raw materials is replaced by waste from the industry, $\mathrm{CO}_{2}$ - $\mathrm{D}$ is reduced. It has been pointed out by Awoyera, et al. [5] that the reuse of some waste materials as concrete constituents provides sustainability in the preservation of natural deposits.

The production, transportation, sale, storage, and use of ceramic products cause a lot of waste. According to Qu and Zheng (2014) [6], thirty percent of the world's ceramic industry waste is produced as industrial waste. The ceramic industry and the construction sector still need to continue to meet economic development, which in turn will increase the waste generated by ceramic production, and how to manage these wastes efficiently becomes an urgent problem. Currently, a topical issue in the construction circles is the reuse of waste ceramics. In every country worldwide, a large amount of this waste is produced annually, and most of it is reusable. According to [7], Nigeria generates over 60 
million tonnes of different wastes annually with less than $10 \%$ waste management capacity. The need to manage these wastes has become one of the most pressing issues of our time, requiring specific actions aimed at reducing waste generation and for wastes already generated, reuse or recycle, and often, engage waste-to-energy systems as a means of exploiting the resources contained within the waste, which would otherwise be lost, thus reducing environmental impact. A million tonnes of these ceramic waste materials are available and discarded every year in the world [8].

Wastes from ceramics products such as tiles are classified as non-hazardous industrial waste; they are produced from natural materials containing a high proportion of clay minerals.

This research aims to obtain sustainable concrete using various combinations of traditional aggregates with construction and demolition ceramics tiles as fine and coarse aggregate and ground ceramics with Portland cement as the binder

This investigation seeks to obtain concrete of enhanced compressive strength using optimal combinations of ground ceramics-for partial replacement of Portland cement; river sand, stone dust, and/or crushed ceramics-for use as fine aggregates; and granite, bush gravel, and coarsely crushed ceramics as coarse aggregates.

\section{Materials}

The cement used in this study was grade 42.5 Dangote $3 \mathrm{X}$ ordinary Portland cement that fulfills the requirements of the British Standards [9]. The fine aggregates used were river sand, stone dust, and fine ceramics while the coarse aggregates included crushed granite, bush gravel, and crushed ceramics of $25 \mathrm{~mm}$ maximum nominal size. In this investigation, ceramics tiles used were sourced from a construction site along University Road in Oye Ekiti, Ekiti State, Nigeria, where they were dumped in large quantities as a waste product. The tiles were first washed to remove the visible earth impurities. Using a jaw crusher, a measured quantity of the ceramics tiles was crushed to a size of $20 \mathrm{~mm}$ (for coarse aggregate) while a separate quantity was pulverized with the aid of a pulverizing machine to sizes less than $4 \mathrm{~mm}$ in diameter, for use as fine aggregates. The portion of the pulverized ceramics intended for replacement of cement was ball-milled to achieve a powdered granulated shape, which was sieved through $75 \mu \mathrm{m}$ sieve and finally sieved through $45 \mu \mathrm{m}$ to achieve a particle size close to the $45 \mu \mathrm{m}$ size of Portland cement. The experimental design for the concrete cube crushing test is shown in Table 1 while the quantities of materials for the concrete mix design are presented in Table 2. Table 3 shows the provisional quantities of materials to be used for the design of concrete for optimal strength.

\section{Methods}

\subsection{Chemical Test on Ground Ceramics}

The chemical test was conducted at the research laboratory of the Engineering 
Table 1. Experimental design of concrete cube crushing test.

\begin{tabular}{|c|c|c|c|}
\hline & Factors & Levels & Descriptions \\
\hline \multirow{5}{*}{ A } & \multicolumn{3}{|c|}{ Percentage Replacement of Cement with Ground Ceramics Tiles (C-C) } \\
\hline & Percentage Replacement (\%) & 4 & $0 \%, 5 \%, 10 \%, 20 \%$ \\
\hline & Curing Age (Days) & 3 & $7,28,56$ \\
\hline & Replicates & 3 & \\
\hline & \multicolumn{2}{|c|}{ Total Number of Cubes $=(4 \times 3 \times 3)$} & 36 \\
\hline \multirow{5}{*}{ B } & \multicolumn{3}{|c|}{ Percentage Replacement of River Sand with Fine Ceramics (F-C) } \\
\hline & Percentage Replacement (\%) & 3 & $5 \%, 10 \%, 20 \%$ \\
\hline & Curing Age (Days) & 3 & $7,28,56$ \\
\hline & Replicates & 3 & \\
\hline & \multicolumn{2}{|c|}{ Total Number of Cubes $=(3 \times 3 \times 3)$} & 27 \\
\hline \multirow{5}{*}{$\mathrm{C}$} & \multicolumn{3}{|c|}{ Percentage Replacement of Stone dust with Fine Ceramics $(S-C)$} \\
\hline & Percentage Replacement (\%) & 4 & $0 \%, 5 \%, 10 \%, 20 \%$ \\
\hline & Curing Age (Days) & 3 & $7,28,56$ \\
\hline & Replicates & 3 & \\
\hline & \multicolumn{2}{|c|}{ Total Number of Cubes $=(4 \times 3 \times 3)$} & 36 \\
\hline \multirow{5}{*}{$\mathrm{D}$} & \multicolumn{3}{|c|}{ Percentage Replacement of Granite with Crushed Ceramics ( $G-C$ ) } \\
\hline & Percentage Replacement (\%) & 3 & $5 \%, 10 \%, 20 \%$ \\
\hline & Curing Age (Days) & 3 & $7,28,56$ \\
\hline & Replicates & 3 & \\
\hline & \multicolumn{2}{|c|}{ Total Number of Cubes $=(3 \times 3 \times 3)$} & 27 \\
\hline \multirow{6}{*}{$\mathrm{E}$} & \multicolumn{3}{|c|}{ Percentage Replacement of Gravel with Crushed Ceramics (B-C) } \\
\hline & Percentage Replacement (\%) & 4 & $0 \%, 5 \%, 10 \%, 20 \%$ \\
\hline & Curing Age (Days) & 3 & $7,28,56$ \\
\hline & Replicates & 3 & \\
\hline & \multicolumn{2}{|c|}{ Total Number of Cubes $=(4 \times 3 \times 3)$} & 36 \\
\hline & TOTAL NUMBER OF CUBE & $7+36+36)$ & 162 \\
\hline
\end{tabular}

Table 2. Mix components for test concrete.

\begin{tabular}{|c|c|c|c|c|c|c|}
\hline & Mixing Designs & $\begin{array}{c}\text { Percentage } \\
\text { Replacement } \\
\text { (\%) }\end{array}$ & $\begin{array}{l}\text { Cement } \\
(\mathrm{kg})\end{array}$ & $\begin{array}{c}\text { Fine } \\
\text { Aggregate } \\
(\mathrm{kg})\end{array}$ & $\begin{array}{c}\text { Coarse } \\
\text { Aggregate } \\
(\mathrm{kg})\end{array}$ & $\begin{array}{c}\text { Ceramics } \\
\text { Content } \\
(\mathrm{kg})\end{array}$ \\
\hline \multirow{4}{*}{1} & \multirow{4}{*}{$\begin{array}{l}\mathrm{OPC}+\mathrm{GCT} \\
(\mathrm{C}-\mathrm{C})\end{array}$} & $0 \%$ & 3.04 & 7 & 12.7 & 0 \\
\hline & & $5 \%$ & 2.89 & 7 & 12.7 & 0.15 \\
\hline & & $10 \%$ & 2.74 & 7 & 12.7 & 0.30 \\
\hline & & $20 \%$ & 2.43 & 7 & 12.7 & 0.61 \\
\hline \multirow{4}{*}{2} & \multirow{4}{*}{$\begin{array}{l}\text { River Sand + Fine Ceramics } \\
\qquad(\mathrm{F}-\mathrm{C})\end{array}$} & $5 \%$ & 3.04 & 6.7 & 12.7 & 0.35 \\
\hline & & $10 \%$ & 3.04 & 6.3 & 12.7 & 0.70 \\
\hline & & $20 \%$ & 3.04 & 5.6 & 12.7 & 1.40 \\
\hline & & & 9.12 & 18.6 & 38.1 & 2.45 \\
\hline
\end{tabular}




\section{Continued}

\begin{tabular}{|c|c|c|c|c|c|c|}
\hline \multirow{5}{*}{3} & & $0 \%$ & 3.04 & 7 & 12.7 & 0 \\
\hline & Stone Dust + Fine Ceramics & & & & & \\
\hline & (S-C) & $5 \%$ & 3.04 & 6.7 & 12.8 & 0.4 \\
\hline & (Stone Dust Is Used & $10 \%$ & 3.04 & 6.3 & 12.7 & 0.7 \\
\hline & & $20 \%$ & 3.04 & 5.6 & 12.7 & 1.4 \\
\hline \multirow{3}{*}{4} & & $5 \%$ & 3.04 & 7 & 12.07 & 0.64 \\
\hline & Granite + Crushed Ceramics & $10 \%$ & 3.04 & 7 & 11.43 & 1.27 \\
\hline & & $20 \%$ & 3.04 & 7 & 10.16 & 2.54 \\
\hline \multirow{5}{*}{5} & & $0 \%$ & 3.04 & 7 & 12.7 & 0 \\
\hline & Gravel + Crushed Ceramics & $5 \%$ & 3.04 & 7 & 12.07 & 0.64 \\
\hline & (Gravel Is Used as & $10 \%$ & 3.04 & 7 & 11.43 & 1.27 \\
\hline & Coarse Aggregate) & & & & & \\
\hline & & $20 \%$ & 3.04 & 7 & 10.16 & 2.54 \\
\hline \multicolumn{3}{|c|}{ Total of Components } & 53.66 & 121.2 & 219.72 & 15.97 \\
\hline
\end{tabular}

Table 3. The provisional materials for the design of concrete from optimal strength.

\begin{tabular}{cccccccc}
\hline \multicolumn{2}{c}{ Binary Cement } & \multicolumn{2}{c}{ Ternary fine aggregate } & \multicolumn{3}{c}{ Ternary coarse aggregate } \\
\hline $\begin{array}{c}\text { Grounded } \\
\text { Ceramics }(\mathrm{g})\end{array}$ & OPC $(\mathrm{g})$ & Fine Ceramics $(\mathrm{g})$ & Stone dust $(\mathrm{g})$ & River sand (g) & $\begin{array}{c}\text { Crushed } \\
\text { Ceramics }(\mathrm{g})\end{array}$ & Bush Gravel (g) & Granite (g) \\
\hline 150 & 2890 & 350 & 320 & 6330 & 640 & 580 & 11500 \\
\hline
\end{tabular}

Materials Development Institute (EMDI), Akure using Energy Dispersive X-ray Fluorescence Spectrometer (EDXRF), brand EDX3600B, as shown in Plate 1. The system has a vacuum pump for light element detection and a helium injection system for liquids analysis. The Ground Ceramics sample was first made into a pellet form (Plate 2) before loading it into the machine. The X-ray fluorescence analysis was carried out to determine the elemental composition of the Ground Ceramic Tiles, which was further converted to the oxide composition using [10].

\subsection{Natural Moisture Content of the Fine Aggregate}

At a temperature of $105^{\circ} \mathrm{C} \pm 5^{\circ} \mathrm{C}$, the test portion of the fine aggregates (river sand and fine ceramics) was taken in a container and dried until it reached a constant mass. The moisture content was measured by expressing the mass of the total moisture in the sample as a percentage of the mass of the dry sample. Procedure descriptions were in line with BS [11].

\subsection{Grading of the Aggregates and Ceramics wastes}

The sieve analysis of coarse aggregate (granite, bush gravel, and crushed ceramics), fine aggregate (river sand, stone dust, and fine ceramics), and ground ceramics used for casting the concrete mixes under investigation was performed in the Structural Laboratory of the Civil Engineering Department, FUTA. The 


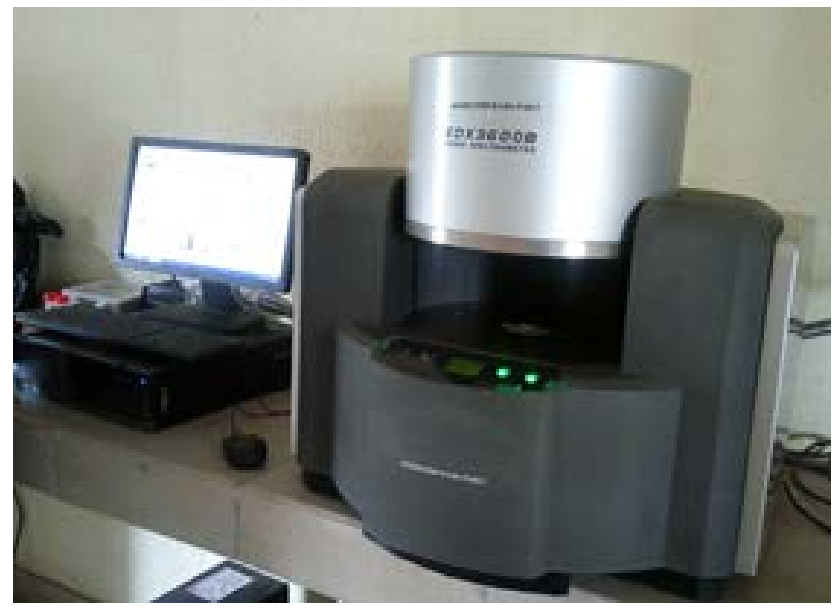

Plate 1. EDX3600B EDXRF spectrometer machine.

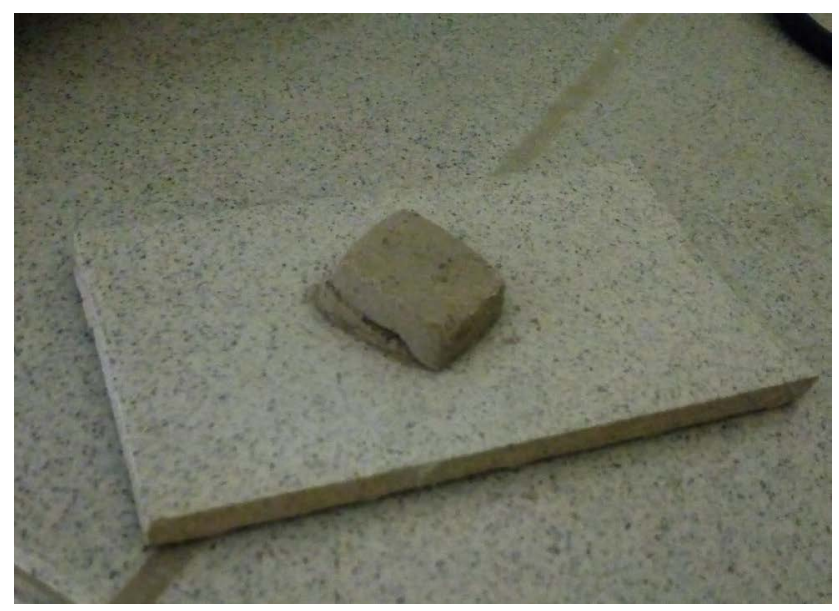

Plate 2. Sample of ceramics before loading into the XRF unit.

sieves were arranged from $25 \mathrm{~mm}-4.76 \mathrm{~mm}$ for granite, bush gravel, and crushed ceramics, $4.75 \mathrm{~mm}-72 \mu \mathrm{m}$ for river sand, stone dust, and fine ceramics, and $500 \mu \mathrm{m}-45 \mu \mathrm{m}$ for grounded ceramics. The percentage retained on each sieve was computed by dividing the weight retained on each sieve by the original sample mass while the percentage passing (or percentage finer) was computed by starting with $100 \%$ and subtracting the percentage retained on each sieve as a cumulative procedure. The entire procedure used was following BS [12].

\subsection{Bulk Density}

The bulk density test was conducted under the provisions of BS [13] for granite, bush gravel, crushed ceramics, river sand, stone dust, fine ceramics, and grounded ceramics. The test was carried out in a weighted metal cylinder with a specified height and diameter. The container was filled into three layers to find the compacted bulk density, stamping each layer with a rod. The overflow was extracted and the density of the bulk was measured as the ratio of the sample's net mass in the cylinder to its volume. 


\subsection{Specific Gravity}

The specific gravity test was performed based on the guidelines of the British Standard [14] on fine aggregates (river sand, stone dust, and fine ceramics), coarse aggregates (granite, bush gravel, and crushed ceramics), and grounded ceramics. The specific gravity was determined as the ratio between the mass of the sample and the mass of the equivalent water volume.

\subsection{Standard Consistency}

The test was carried out in compliance with the requirements of BS [15] on grade 42.5 Dangote 3X ordinary Portland cement and on each of the cement materials resulting from different percentage replacements of OPC with grounded ceramics. Vicat's regular equipment was used. In the test, the device's plunger was allowed to penetrate $33 \mathrm{~mm}$ from the top of each of the molds' cement pastes. As a standard consistency for each paste, the ratio of the mass of water needed to obtain a paste that allows $33 \mathrm{~mm}$ of penetration to the mass of the cement material (in percentage terms) was reported.

\subsection{Setting Time}

The initial and final setting times were determined both for the OPC and for each of the pastes obtained by partially replacing OPC with the grounded ceramics. The initial setting time was calculated as the time from the moment water was added to the paste to the moment the paste began to lose its plasticity. The final setting time was calculated as the time from the moment water was added to the paste to the time the paste lost its plasticity fully and obtained adequate firmness to withstand certain definite pressure. This test was conducted according to the recommendations of BS [15].

\subsection{Aggregate Crushing Value (ACV) of the Coarse Aggregate}

This test was carried out following British Standard [16]. The sample was filled into the mould in three layers and given 25 tamping at each layer. The weight was measured as $A$. The apparatus was then placed in the compression testing machine and loaded at a uniform rate to achieve a $40 \mathrm{kN}$ load in 10 minutes. After this, the load was released. The sample was then sieved through a $2.36 \mathrm{~mm}$ sieve and the fraction passing through the sieve was weighed as $B$. Aggregate crushing value was computed as $(B \div A) \times 100$. The test was carried out three times and the average was taken as the ACV value.

\subsection{Aggregate Impact Value (AIV) of the Coarse Aggregate}

This test was carried out and it was done following British Standard [16]. Sample passing through $12.5 \mathrm{~mm}$ sieve and retained on a $10 \mathrm{~mm}$ sieve was used. The sample was filled into the mold at three layers and given 25 tamping at each layer and it was weighted in gram as weight " $C$ ". The sample was loaded into the AIV machine and subjected to a total of 15 blows, each being delivered at an in- 
terval of not less than one second. The sample was removed and sieved through a $2.36 \mathrm{~mm}$ sieve the fraction passing through was weighed in gram as weight

" $B$ ". Three such tests were carried out and the mean of the results was reported. Aggregate impact value was computed as $(C \div B) \times 100$.

\subsection{Fineness}

According to BS [9], this test was performed using the dry sieving technique. OPC and grounded ceramics were poured in a $45 \mu \mathrm{m}$ sieve and carefully shaken for 8 minutes. The fineness of the $45 \mu \mathrm{m}$ sieve was expressed in terms of the percentage weight of the residue and was measured as the ratio of the sample mass retained in the $45 \mu \mathrm{m}$ sieve to the total sample mass.

\subsection{Slump}

The 1:2:4 concrete mix ratio was batched by volume and prepared with a 0.55 water to cement ratio. The drop in the slumped concrete's height was taken as the slump. This experiment was conducted per British Standard [17].

\subsection{Compacting Factor}

The test was conducted in compliance with BS [17]. A mass ratio, i.e. the ratio of the mass of the partially compacted concrete to the mass of the same concrete completely compacted, was used to calculate the degree of compaction called the compacting factor.

\subsection{Batching of Concrete and Compressive Strength}

The batching of the concrete was in the weight of 1:2:4 and the water to cement ratio was 0.55 . Table 1 shows the Five different concrete mix designs used for this test with each natural aggregate (Sand and Stone dust), (Granite and Bush gravel) and Ordinary Portland Cement partially replaced with ceramic tiles in the percentage of $0 \%, 5 \%, 10 \% \& 20 \% .150 \times 150 \times 150 \mathrm{~mm}^{3}$ molds were used for casting. Compaction of concrete was achieved by placement in three layers and rodding each layer with a $16 \mathrm{~mm}$ rod. The concrete was left in the mold and allowed to sit for 24 hours before the cubes were demoulded and placed in a curing tank. The concrete cubes were cured by complete immersion in water for 7,28 , and 56 days. One hundred and sixty-two (162) cubes were cast with 0.55 water/cement ratio and crushing tests were carried out using a compression machine following the procedure of BS [18].

\section{Results and Discussions}

\subsection{Chemical Test of Grounded Ceramics}

Table 4 presents the outcome of the chemical examination of grounded ceramics. ASTM [19] stated that the addition of $\mathrm{Al}_{2} \mathrm{O}_{3}, \mathrm{SiO}_{2}$, and $\mathrm{Fe}_{2} \mathrm{O}_{3}$ must give at least $70 \%$ of the total oxide composition for a substance to be regarded as a pozzolan. 
Table 4. Oxides composition of grounded ceramics tiles.

\begin{tabular}{ccccccccccc}
\hline Compound & $\mathrm{Al}_{2} \mathrm{O}_{3}$ & $\mathrm{SiO}_{2}$ & $\mathrm{Fe}_{2} \mathrm{O}_{3}$ & $\mathrm{SO}_{3}$ & $\mathrm{~K}_{2} \mathrm{O}$ & $\mathrm{CaO}$ & $\mathrm{ZnO}$ & $\mathrm{PbO}_{2}$ & $\mathrm{MnO}$ & $\mathrm{TiO}_{2}$ \\
\hline $\begin{array}{c}\text { Oxides (\%) in } \\
\text { Grounded Ceramics }\end{array}$ & 20.26 & 73.54 & 3.54 & 1.01 & 3.96 & 0.75 & 0.17 & 0.03 & 0.02 & 0.26 \\
\hline
\end{tabular}

$\mathrm{Al}_{2} \mathrm{O}_{3}+\mathrm{SiO}_{2}+\mathrm{Fe}_{2} \mathrm{O}_{3}$ for grounded ceramics gave $97.34 \%$ of the result obtained and shown in Table 4. This satisfies the necessity for [19]. For grounded ceramics, the ignition loss (LOI) achieved was 9.33 percent. This value, as given in ASTM C618 - 19:2019, is less than the 10 percent limit needed for pozzolan. As a result, grounded ceramics can be regarded as a Class $\mathrm{N}$ pozzolan based on the chemical test findings. Figure 1 shows the graphical representation of the elements present in the ceramics sample.

\subsection{Physical Properties of Aggregates and Ground Ceramics}

Table 5 shows the results of the physical properties tests of the aggregates and the ground ceramics for the concrete test. The table shows that the natural moisture content and the specific gravity of the aggregates are appropriate for making normal concrete. The specific gravity of the ground ceramic tiles is very close to that of the ordinary Portland cement used. The bulk density of the ground ceramics is higher at $2980 \mathrm{~kg} / \mathrm{m}^{3}$ than that of OPC, which is $1378 \mathrm{~kg} / \mathrm{m}^{3}$. The implication is that a denser concrete will be produced when OPC is partially replaced with ground ceramic tiles. The aggregate crushing value (ACV) and aggregate impact value (AIV) for ceramic waste were found to be lower than that of natural coarse aggregates and this suggests the possibility of a reduction in the compressive strength because ceramic waste exhibited a lower capacity to resist the load.

\subsection{Grading of the Aggregates}

Table 5 shows the computed coefficient of uniformity $\left(\mathrm{C}_{\mathrm{u}}\right)$ and also the coefficient of curvature $\left(\mathrm{C}_{c}\right)$ of both fine and coarse aggregates from the results of the sieve analysis conducted on the materials. Grading curves show that the sand, stone dust, granite, bush gravel, and ceramic waste were well-graded and suitable for the production of concrete. Figure 2 and Figure 3 present the grain size analyses of the materials (fine aggregates, coarse aggregates, and ceramic waste) used.

\subsection{Standard Consistency}

Table 6 presents the results of the standard consistency test for OPC and the relevant replacement levels of OPC with grounded ceramics. The table shows that as the replacement level of Portland cement with grounded ceramics rises, the amount of water required to achieve the desired consistency increases. This is due to the high clay content in ceramics, which, as it is known, increases the material's water absorption capacity, as expected. 


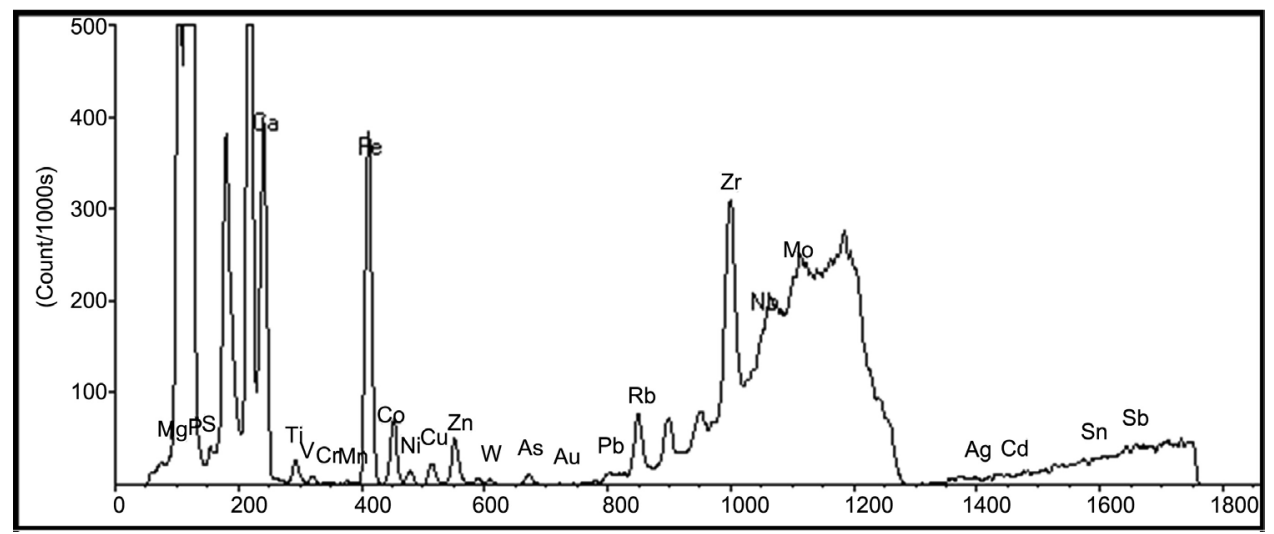

Figure 1. Elemental composition of the ceramics sample.

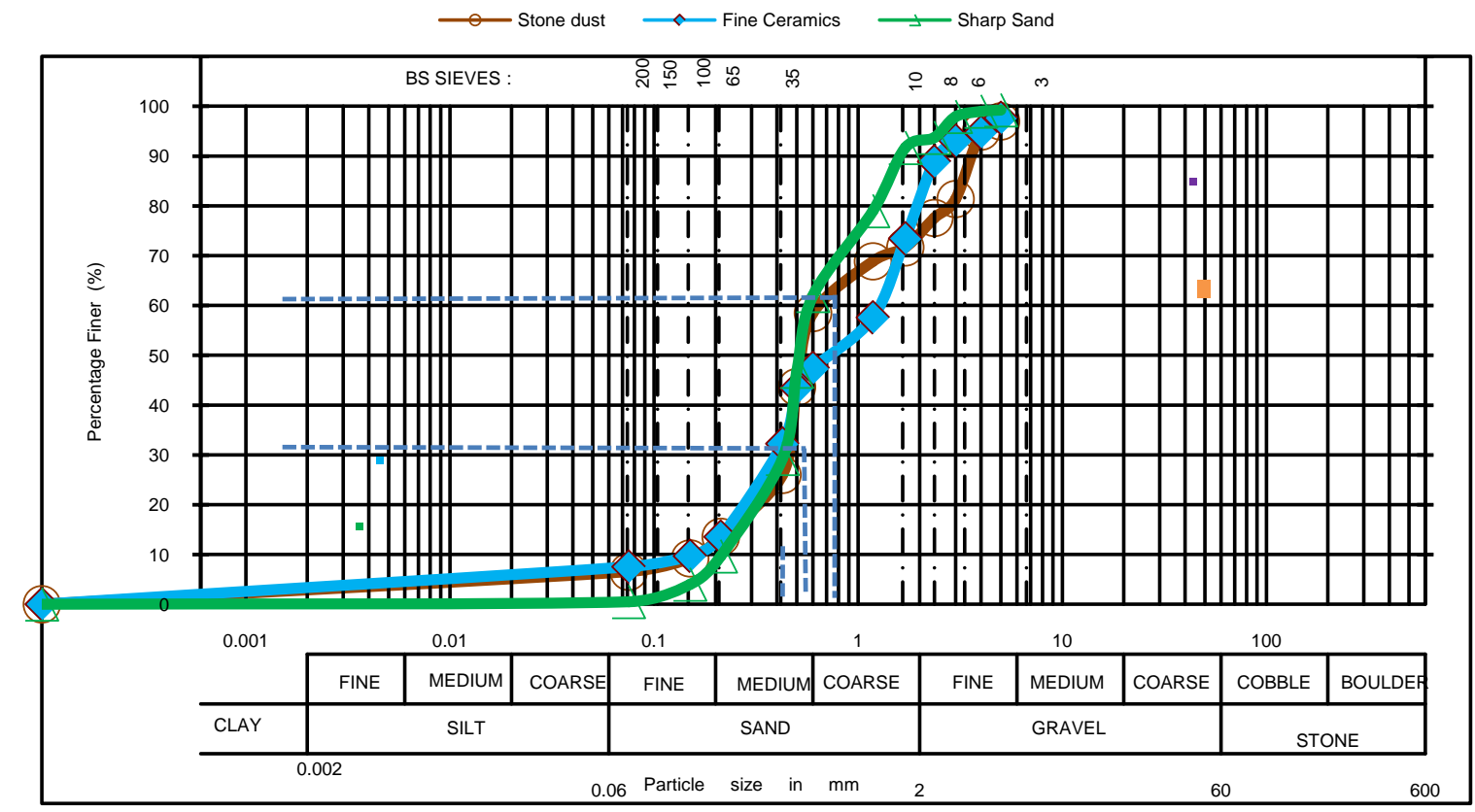

Figure 2. Particle size distribution curves for fine aggregates (fine ceramics, sharp sand, stone dust).

Table 5. Physical properties of aggregates and ceramics materials.

\begin{tabular}{|c|c|c|c|c|c|c|c|c|}
\hline \multirow{2}{*}{$\begin{array}{l}\text { Physical Property } \\
\text { of all Materials Used }\end{array}$} & \multicolumn{3}{|c|}{ Fine Aggregate } & \multicolumn{3}{|c|}{ Coarse Aggregate } & \multicolumn{2}{|c|}{ Cement } \\
\hline & Sand & Stone dust & Fine ceramics & Granite & Bush gravel & $\begin{array}{l}\text { Crushed } \\
\text { ceramics }\end{array}$ & $\begin{array}{c}\text { Portland } \\
\text { cement }\end{array}$ & $\begin{array}{c}\text { Grounded } \\
\text { ceramics }\end{array}$ \\
\hline Fineness (\%) & - & - & - & - & - & - & $98.9 \%$ & $100 \%$ \\
\hline Moisture Content (\%) & $5.56 \%$ & $2.31 \%$ & $9.5 \%$ & - & - & - & - & - \\
\hline Uniformity Coefficient $\left(C_{u}\right)$ & 5.93 & 4.33 & 2.82 & 2.7 & 3.84 & 2.4 & - & - \\
\hline Coefficient of Curvature $\left(C_{c}\right)$ & 0.85 & 2.077 & 1.42 & 1.26 & 0.68 & 0.94 & - & - \\
\hline Specify Gravity & 2.0 & 1.65 & 2.8 & 2.59 & 3.24 & 3.26 & 2.68 & 2.71 \\
\hline Bulk Density $\left(\mathrm{kg} / \mathrm{m}^{3}\right)$ & 1645 & 1453 & 2456 & 2701 & 1590 & 2124 & 1378 & 2980 \\
\hline Aggregate Crushing Value (\%) & - & - & - & 21.02 & 20.3 & 18.38 & - & - \\
\hline Aggregate Impact Value (\%) & - & - & - & 19.78 & 19.85 & 17.20 & - & - \\
\hline Water Absorption (\%) & - & - & - & 2.12 & 6.59 & 29.9 & - & - \\
\hline
\end{tabular}




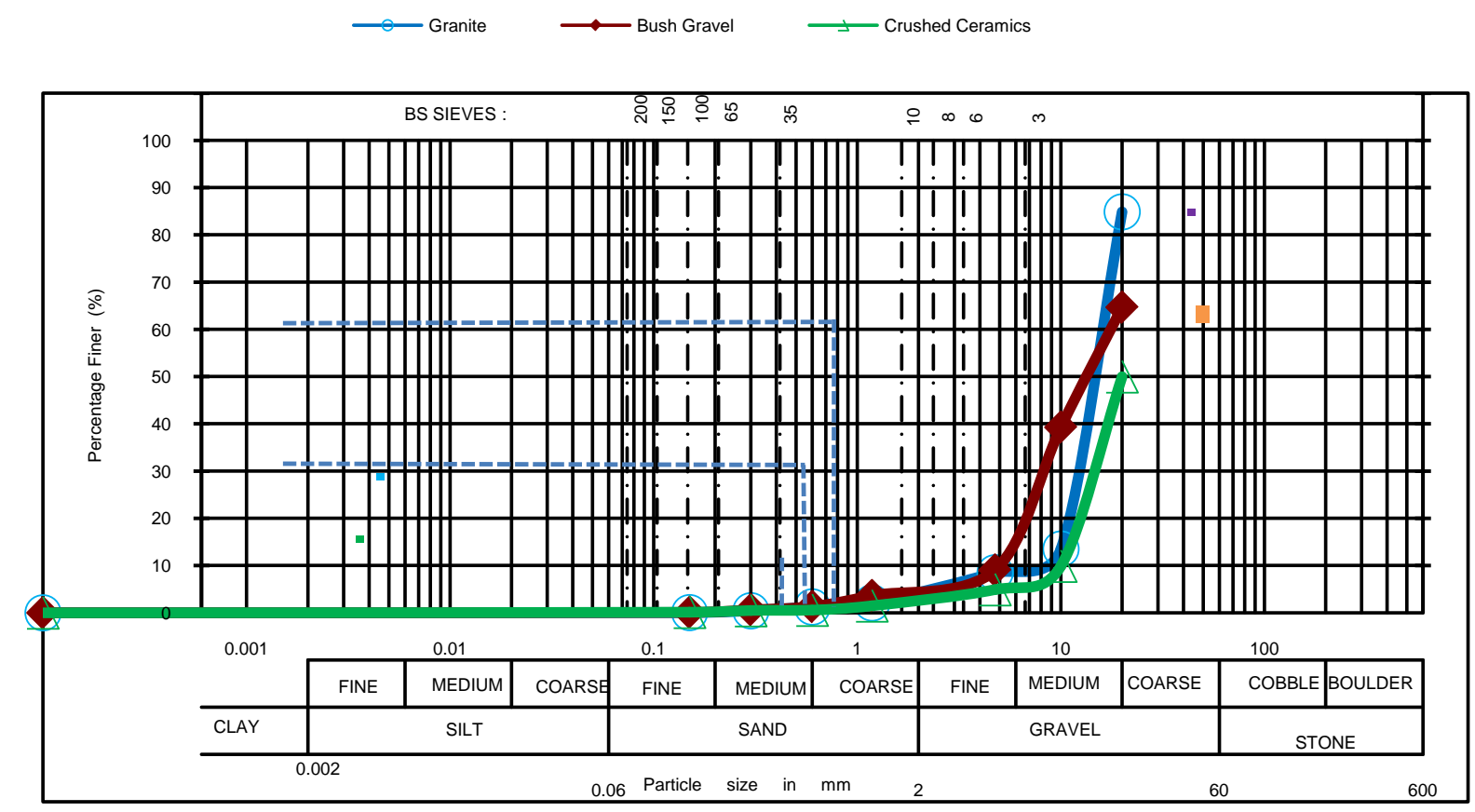

Figure 3. Particle size distribution curves for coarse aggregates (crushed ceramics, gravel and granite).

Table 6. Standard consistency test result and setting time test result.

\begin{tabular}{ccccc}
\hline Replacement of OPC by GCT (\%) & $\mathbf{0}$ & $\mathbf{5}$ & 10 & $\mathbf{2 0}$ \\
\hline Mass of cement (g) & 400 & 380 & 360 & 320 \\
Mass of GCT (g) & 0 & 20 & 40 & 80 \\
Mass of water (g) & 122 & 127.5 & 150.7 & 199.6 \\
Water content (\%) & 29.8 & 37.0 & 41.8 & 47 \\
Initial setting time (min) & 46 & 51 & 84 & 125 \\
Final setting time (min) & 590 & 905 & 1396 & 1501 \\
\hline
\end{tabular}

\subsection{Setting Time}

The results of the setting times test for OPC and various replacements are shown in Table 6. Although both the initial and final setting times of the replacement were longer than those of the control paste, the initial setting times were greater than the 45 mins recommended minimum while the final setting times were more than the maximum 600 mins recommended maximum according to BS EN 196-1:2005. Therefore, at the replacement levels used in this work, the addition of ground ceramics to Ordinary Portland Cement affects the initial and final setting time of concrete binder.

\subsection{Fineness}

The result of the fineness test is presented in Table 5. The cement has a fineness percentage of $98.9 \%$ of why the grounded ceramics as the fineness of $100 \%$ this is because the ceramics have been passed through $45 \mu \mathrm{m}$ sieve before it was uti- 
lized in concrete production.

\subsection{Tests on fresh Concrete}

The tests conducted on fresh concrete include slump, compacting factor. The results of these tests are shown in Table 7 . The table shows that the workability of concrete decreases with an increase in the replacement level of OPC by grounded ceramics tiles. Except for the Stone dust with fine ceramics replacement (S-C) whose slump increase with an increase in the percentage of ceramics waste present. This is an indication that the inclusion of ceramic waste in the mix affects the cohesiveness of the mix. This decrease and increase in slump value with an increase in ceramic waste content can be attributed to higher water absorption capacity and the angular shape of the ceramic waste. To use these Ceramics more effectively, more water needs to be added to achieve a more workable fresh concrete.

\subsection{Compressive Strength}

The compressive strength of concrete cube specimens for different percentages of ceramic waste is shown in Figures 4-10. It was observed that the compressive strength of concrete decreases with increases in the presence of ceramics waste in all the 5 mix designs for this investigation. Compressive strength of concrete from ground ceramics tiles as a partial replacement for the ordinary Portland cement decrease as the percentage of grounded ceramics increased from $0 \%$ to

Table 7. Test results on fresh concrete.

\begin{tabular}{cccccc}
\hline Mix Design/Percentage & C-C & F-C & G-C & S-C & B-C \\
\hline 0 & 40.3 & 40.3 & & 29 & 70 \\
$5 \%$ & 38 & 35.7 & 42.3 & 31.3 & 64 \\
$10 \%$ & 35 & 34 & 59 & 32.7 & 51.7 \\
$20 \%$ & 31.3 & 32 & 41.7 & 45.7 & 58.7 \\
\hline
\end{tabular}

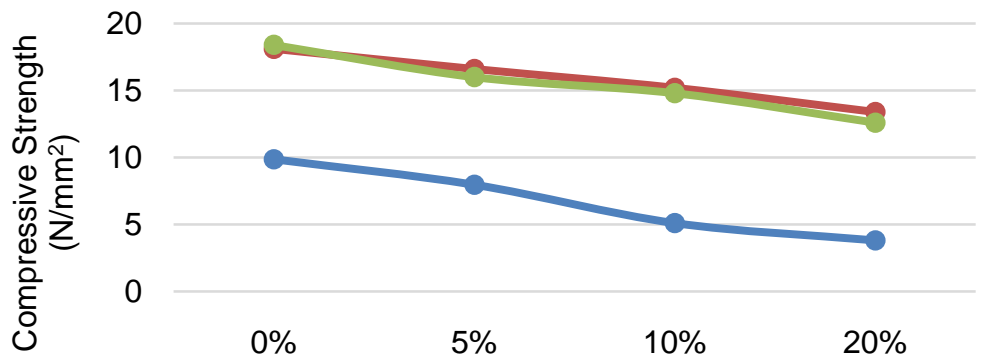

Percentage replacement of Grounded ceramics

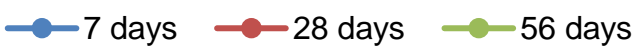

Figure 4. Curve for the compressive strength of concrete with grounded ceramics content as partial replacement for ordinary Portland cement. 


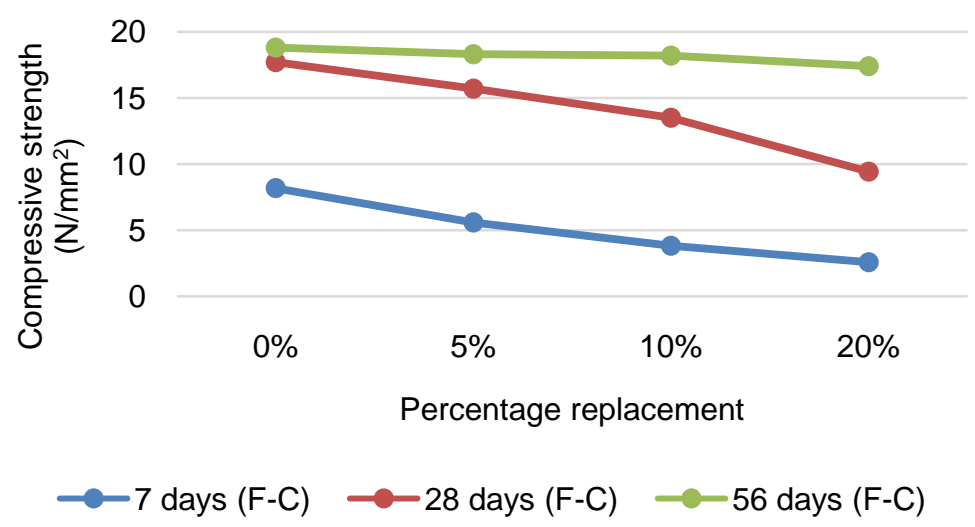

Figure 5. Curve for the compressive strength of concrete with fine ceramics content as partial replacement for sharp sand (River sand).

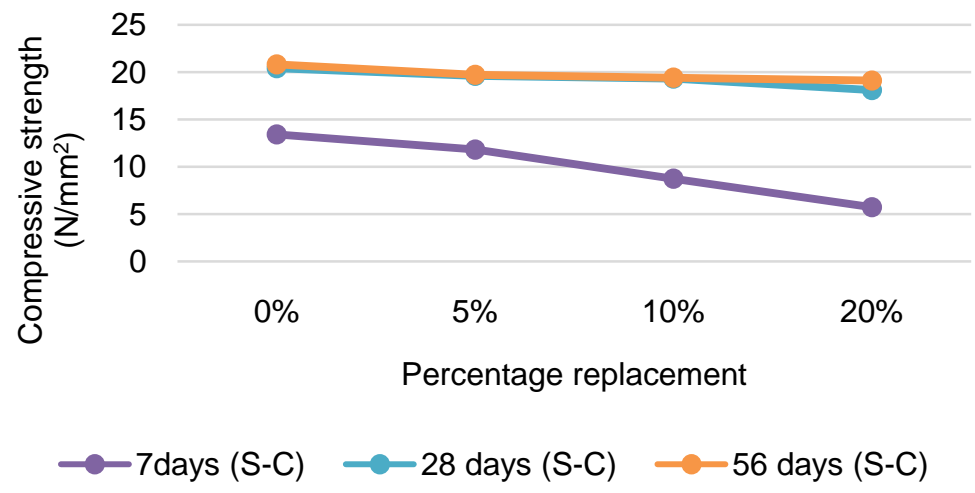

Figure 6. Curve for the compressive strength of concrete with fine ceramics content as partial replacement for Stone dust.

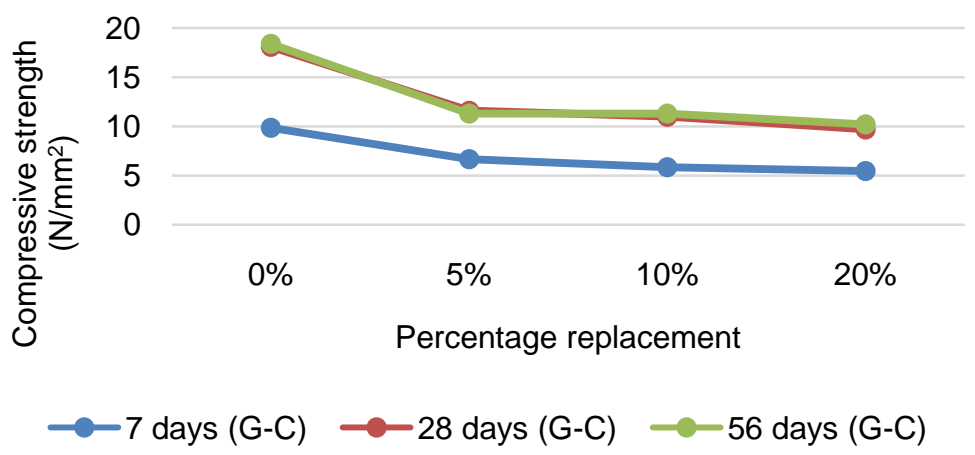

Figure 7. Curve for the compressive strength of concrete with crushed ceramics content as partial replacement for granite.

$20 \%$ resulting in a $25 \%$ decrease in the optimum compression strength (at 28 days) which is $18.10 \mathrm{~N} / \mathrm{mm}^{2}$ but there is a slight increase in the optimum strength when the concrete was cured till 56 days this is as a result of the pozzolanic effect of the grounded ceramics. Compressive strength of concrete from fine ceramics as a partial replacement for river sand and concrete from crushed ceramics as a partial replacement for granite decrease as the percentage of the 


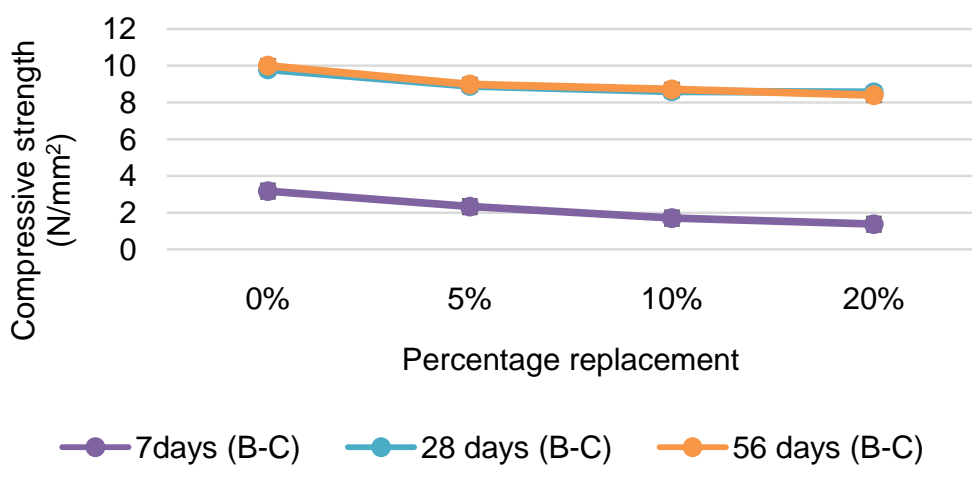

Figure 8. Curve for the compressive strength of concrete with crushed ceramics content as partial replacement for gravel.

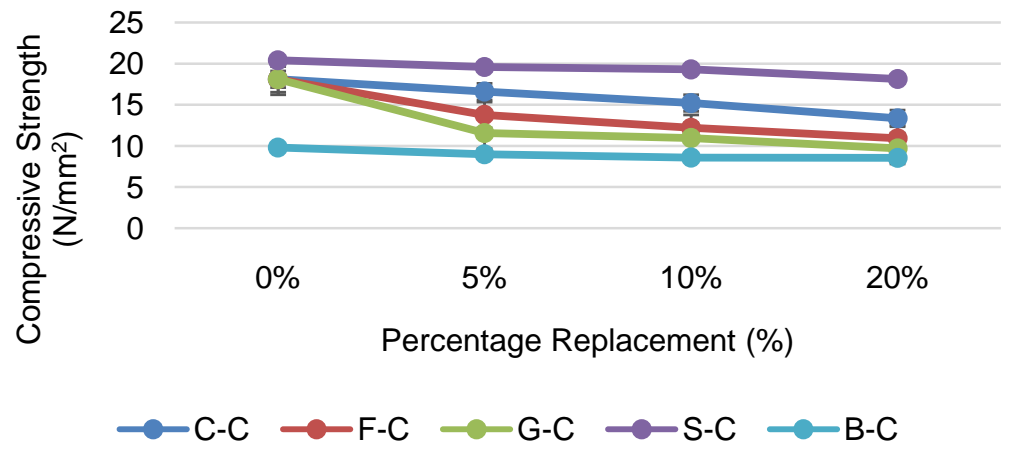

Figure 9. Curve for the compressive strength of concrete produced from replacing concrete constituent with ceramics content at various percentages at 28 days.

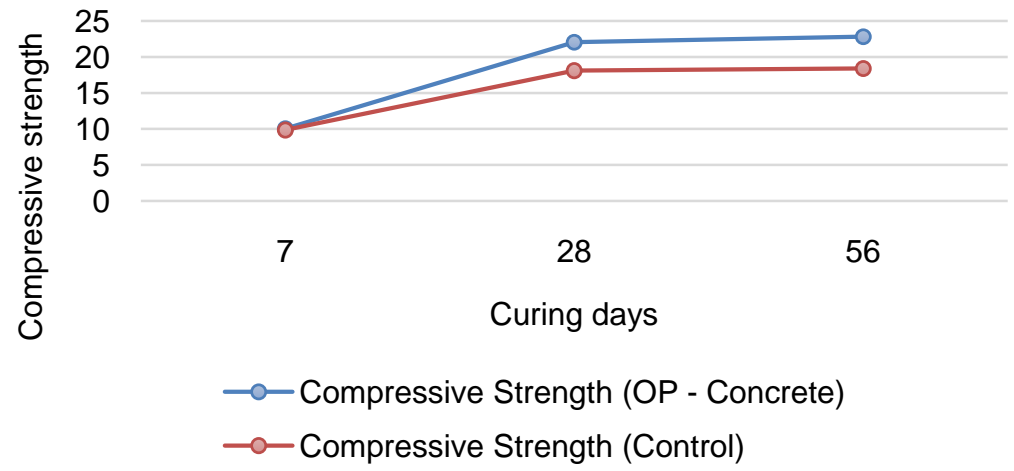

Figure 10. Comparison between the control concrete and the optimum concrete.

ceramics aggregates increased from $0 \%$ to $20 \%$ resulting in $45 \%$ and $11.3 \%$ decrease respectively in the optimum compressive strength which is $18.10 \mathrm{~N} / \mathrm{mm}^{2}$. Compressive strength of concrete from fine ceramics as partial replacement and stone dust as a full replacement for river sand, decrease as the percentage of fine ceramics increase, giving $11.3 \%$ and $12.7 \%$ decrease respectively. Likewise, the concrete produced from crushed ceramics as a partial replacement of coarse aggregate (Granite) and bush gravel, as a full replacement for granite decrease as the percentage of the crushed ceramics increase in the concrete mix, resulting in 
$11.3 \%$ and $12.7 \%$ decrease respectively.

The reaction of stone dust with fine ceramics at different proportions produce a higher strength concrete with optimum strength of $20.40 \mathrm{~N} / \mathrm{mm}^{2}$ compared to others this as a result of the bonding properties of the matrix of the stone dust and fine ceramics, while the reaction of bush gravel with crushed ceramics produce a very low strength of $9.79 \mathrm{~N} / \mathrm{mm}^{2}$. The decrease in strength is due to the flaky nature and the smooth surface texture of ceramic waste aggregate; which resulted in poor bonding properties of the matrix. Table 3 shows the mix proportions of the various constituents (Binary cement, ternary fine and coarse aggregates) used in the production of the concrete for the evaluation of the compressive strength of concrete produced from binary cement and ternary fine and coarse aggregates which were derived from the graphs in Figures 4-9. The graphs show that the optimum compressive strength of the concrete from all the concrete mix groups was obtained when the ceramics wastes were used to replace the various concrete constituents at $5 \%$.

From Figure 7, it was observed that the OP concrete has a higher compressive strength compared to the control concrete and the strength values increased progressively as the curing age increased; an indication of the effect of curing age on concrete strength development.

\subsection{Statistics and Analysis of Variance (ANOVA)}

Table 8 provides the mean and standard deviation for each combination of the groups of the independent variables (the Percentages and the curing age). A two-way ANOVA was conducted to examine the effect of the percentage replacement of concrete components with ceramics tiles, in the analysis of variances (ANOVA) table as shown in Table 9 we can see from the table that there is no statistically significant difference in the means of the compressive strength of concrete of various groups $(\mathrm{p}=0.214>0.05)$.

As shown in Table 10, the Post hoc comparisons using the LSD (Least Significant Difference) test indicated that There were statistically significant differences only when the concrete constituents were replaced with ceramics tile at $20 \%(p=0.049)$.

Table 8. Descriptive statistics table.

\begin{tabular}{ccccc}
\hline Curing Age (Days) & Percentage & Mean & Std. Deviation & N \\
\hline 0 & 9.2300 & 3.71831 & 5 \\
7 & 0.05 & 7.3960 & 3.41261 & 5 \\
& 0.1 & 5.5320 & 2.53765 & 5 \\
& 0.2 & 4.0800 & 1.73296 & 5 \\
& Total & 6.5595 & 3.36259 & 20 \\
\hline \multirow{2}{*}{28} & 0 & 16.8980 & 4.09640 & 5 \\
& 0.05 & 14.0980 & 4.18282 & 5 \\
& 0.1 & 13.2380 & 4.13838 & 5 \\
\hline
\end{tabular}


Continued

\begin{tabular}{ccccc}
\hline & 0.2 & 12.1300 & 3.79104 & 5 \\
Total & 14.0910 & 4.13815 & 20 \\
\hline 0 & 17.2000 & 4.15692 & 5 \\
56 & 0.05 & 14.1760 & 4.29638 & 5 \\
& 0.1 & 13.4020 & 4.13842 & 5 \\
& 0.2 & 12.4380 & 4.16812 & 5 \\
& Total & 14.3040 & 4.25780 & 20 \\
\hline
\end{tabular}

Table 9. Tests of between-subjects effects.

\begin{tabular}{cccccc}
\hline Source & Type III Sum of Squares & df & Mean Square & F & Sig. \\
\hline Intercept & 8145.447 & 1 & 8145.447 & 206.726 & 0.000 \\
Percentage & 196.903 & 3 & 65.634 & 1.666 & 0.214 \\
Error & 630.436 & 16 & 39.402 & & \\
\hline
\end{tabular}

Table 10. LSD post hoc test analysis table.

\begin{tabular}{|c|c|c|c|c|c|c|}
\hline \multirow{2}{*}{$\begin{array}{c}\text { (I) } \\
\text { Percentage }\end{array}$} & \multirow{2}{*}{$\begin{array}{c}(\mathrm{J}) \\
\text { Percentage }\end{array}$} & \multirow{2}{*}{$\begin{array}{c}\text { Mean } \\
\text { Difference (I-J) }\end{array}$} & \multirow{2}{*}{ Std. Error } & \multirow{2}{*}{ Sig. } & \multicolumn{2}{|c|}{ 95\% Confidence Interval } \\
\hline & & & & & Lower Bound & per Bound \\
\hline & 0.05 & 2.5527 & 2.29208 & 0.282 & -2.3063 & 7.4117 \\
\hline \multirow[t]{3}{*}{0} & 0.1 & 3.7187 & 2.29208 & 0.124 & -1.1403 & 8.5777 \\
\hline & 0.2 & $4.8933^{*}$ & 2.29208 & 0.049 & 0.0343 & 9.7523 \\
\hline & 0 & -2.5527 & 2.29208 & 0.282 & -7.4117 & 2.3063 \\
\hline \multirow[t]{3}{*}{0.05} & 0.1 & 1.1660 & 2.29208 & 0.618 & -3.6930 & 6.0250 \\
\hline & 0.2 & 2.3407 & 2.29208 & 0.322 & -2.5183 & 7.1997 \\
\hline & 0 & -3.7187 & 2.29208 & 0.124 & -8.5777 & 1.1403 \\
\hline \multirow[t]{3}{*}{0.1} & 0.05 & -1.1660 & 2.29208 & 0.618 & -6.0250 & 3.6930 \\
\hline & 0.2 & 1.1747 & 2.29208 & 0.615 & -3.6843 & 6.0337 \\
\hline & 0 & $-4.8933^{*}$ & 2.29208 & 0.049 & -9.7523 & -.0343 \\
\hline \multirow[t]{2}{*}{0.2} & 0.05 & -2.3407 & 2.29208 & 0.322 & -7.1997 & 2.5183 \\
\hline & 0.1 & -1.1747 & 2.29208 & 0.615 & -6.0337 & 3.6843 \\
\hline
\end{tabular}

${ }^{\star}$ The mean difference is significant at the 0.05 level.

Taken together, these results suggest that there was a large change in the compressive strength of concrete produced when the concrete constituents (cement, fine aggregate, and coarse aggregates) was replaced with $20 \%$ of it equivalent ceramics constituents (Grounded ceramics, fine ceramics, and crushed ceramics)

\section{Conclusions}

Based on investigations, the following observations are made. All the concretes 
with the various percentage replacements tested have greater compressive strength values at 28 days of curing. The workability of concrete produced by replacement of fine and coarse aggregate with ceramics waste decreases as the percentage level increases, except concrete produced by replacement of stone dust with ceramics waste whose workability increases as the percentage level increases. The investigation further revealed that the compressive strength of concrete produced by utilizing ceramics waste as partial replacement for fine and coarse aggregates decrease as the percentage level of the replacements increase. On the other hand, for concrete produced by the replacement of river sand with stone dust, the compressive strength is higher compared to the compressive strength of the control and so were its various percentage levels. In like manner, the compressive strength of concrete produced by replacement of granite with bush gravel is lower than that of the control and so are its various percentage levels. Concrete produced from binary cement (Grounded ceramics + OPC) and ternary fine (River sand + Stone dust + Fine ceramics) and coarse (granite + gravel + crushed ceramics) aggregates have a higher compressive strength than the control mix. This shows that the use of ceramic waste in concrete production is an effective way of reducing the amount of ceramics waste generated during construction and demolition and this also decreases the use of natural aggregate.

This research has provided optimal concrete mixes in which the interactions among binary cement, ternary fine and coarse aggregates from various combinations of ceramic wastes, and traditional concrete constituents will result in the concrete of enhanced compressive strength. Further studies are recommended to determine other properties of this type of concrete in future research.

\section{Conflicts of Interest}

The authors declare no conflicts of interest regarding the publication of this paper.

\section{References}

[1] Neville, A. (2011) Properties of Concrete. John Wiley Publishers, New York.

[2] Arum, C., Ikumapayi, C.M. and Aralepo, O.G. (2013) Ashes of Biogenic Wastes-Pozzolanicity, Prospects for Use, and Effects on Some Engineering Properties of Concrete. Materials Sciences and Applications, 4, 521-527. https://doi.org/10.4236/msa.2013.49064

[3] Mark, O.G., Ede, A.N., Olofinnade, O., Bamigboye, G. Okeke, C., Oyebisi, S. and Arum, C. (2019) Influence of Some Selected Supplementary Cementitious Materials on Workability and Compressive Strength of Concrete-A Review. 1st International Conference on Sustainable Infrastructural Development, Nigeria, 24-28 June 2019. https://doi.org/10.1088/1757-899X/640/1/012071

[4] Ede, A.N., Bamigboye, G.O., Olofinnade, O.M. and Shittu, K. (2016) "Influence of Portland Cement Brands and Aggregates Sizes on the Compressive Strength of Normal Concrete. Journal of Materials Science, 866, 78-82. https://doi.org/10.4028/www.scientific.net/MSF.866.78 
[5] Awoyera, P.O., Olofinnade, O.M., Busari, A.A., Akinwumi, I.I., Oyefesobi, M. and Ikemefuna, M. (2016) Performance of Steel Slag Aggregate Concrete with Varied Water-Cement Ratio. Journal of Engineering Science and Technology, 78, 125-131. https://doi.org/10.11113/jt.v78.8819

[6] Qu, S. and Zheng, B. (2014) Application of Ceramic Wastes in Concrete. The Open Civil Engineering Journal, 8, 368-372. https://doi.org/10.2174/1874149501408010368

[7] Ehikhuenmen, S.O. and Ikponmwosa, E.E. (2017) "The Effect of Ceramics Waste as Coarse Aggregate on Strength Properties of Concrete. Nigerian Journal of Technology (NIJOTECH), 36, 691-696.

[8] Rawaid, K., Abdul, J., Irshad , A., Wajid, K., Akhtar, N.H. and Jahangir, M. (2012) Reduction in Environmental Problems Using Rice-Husk Ash in Concrete Husk Ash in Concrete. Construction and Building Materials, 30, 360-365.

https://doi.org/10.1016/j.conbuildmat.2011.11.028

[9] BS EN (2000) Specification for Portland Cement. British Standards Institute, London.

[10] Geochemistry Technical Note (2019) Reference Tables: Element to Oxide Conversion Factors. ALS Global.

[11] BS EN (1999) Tests for Mechanical and Physical Properties of Aggregates. Determination of the Water Content by Drying in a Ventilated Oven. British Standards Institution.

[12] BS (1985) Testing Aggregates. Method for Determination of Particle Size Distribution. British Standards Institution, London.

[13] BS EN 1097-3 (1998) Tests for Mechanical and Physical Properties of Aggregates. Determination of Loose Bulk Density and Voids. British Standards Institution.

[14] BS EN 12620:2002+A1 (2008) Specification for Aggregates from Natural Sources for Concrete. British Standards Institution.

[15] BS EN 196-1 (2005) Methods of Testing Cement. Determination of Strength. British Standards Institution.

[16] BS EN 1097-2 (2010) Testing Aggregates. Methods for Determination of Aggregate Crushing Value and Aggregate Impact Value. British Standards Institution.

[17] BS EN 12350-2 (2000) Testing Concrete. Method for Determination of Slump. British Standards Institute.

[18] BS EN 12390-3 (2002) Testing Concrete. Method for Determination of Compressive Strength of Concrete Cubes. British Standards Institution.

[19] ASTM C618-19 (2019) Standard Specification for Coal Fly Ash and Raw or Calcined Natural Pozzolan for Use in Concrete. ASTM International, West Conshohocken. 